\title{
Pre-interruptive intracoronal resorption: clinical and radiographic follow-
} up

\author{
Reabsorção intracoronária pré-eruptiva: acompanhamento clinico e radiográfico
}

\author{
Sâmila Gonçalves BARRA' \\ Maria Isabel de Oliveira e Brito VILLALOBOS' \\ Cláudia Valéria de Sousa Resende PENIDO' \\ Angela Christina Barroso RECCHIONI ${ }^{1}$ \\ Maria Augusta Portella Guedes VISCONTI2
}

\section{ABSTRACT}

Pre-interruptive intracoronal resorption is a radiolucent lesion localized in dentin, immediately below the amelodentin junction of unerupted teeth. It is rare, asymptomatic, and of idiopathic etiology, generally diagnosed in routine radiographs or in those for orthodontic purposes. A conservative approach, with radiographic follow-up is the treatment recommended until the tooth erupts, and then the intervention is made. However, in cases with symptoms or progression of the lesion, surgical intervention is advisable. To report a case of pre-interruptive intracoronal resorption, with a conservative approach, showing the clinical and radiographic follow-up of this condition. The patient, a nineyear-old Caucasian girl, presented to the Dental Clinic for routine examination. An initial panoramic radiograph was requested, which showed an intracoronal radiolucence in tooth 45 that had not yet erupted. Clinical and radiographic follow-up was made until the affected tooth was completely established in the oral cavity. The treatment recommended for pre-interruptive intracoronal resorption is to have knowledge of the phenomenon, associate its probable etiology and radiographic aspect, as well as its prevalence, occurrence and treatment options, by considering a conservative approach when there are no symptoms.

Indexing terms: Dental caries. Dental radiography. Permanent dentition. Tooth resorption. Unerupted tooth.

\section{RESUMO}

A reabsorção intracoronária pré-eruptiva é uma lesão radiolúcida localizada na dentina, logo abaixo da junção amelo-detinária de dentes não irrompidos. É rara, assintomática e de etiologia idiopática, geralmente diagnosticada em exames radiográficos de rotina ou com fins ortodônticos. Uma abordagem conservadora com acompanhamento radiográfico é o tratamento recomendado até que o dente erupcione para ser feita a intervenção. Porém, em casos de sintomatologia ou progressão da lesão, aconselha-se a intervenção cirúrgica. Objetivo: Relatar o caso de reabsorção intracoronária pré-eruptiva, com uma abordagem conservadora mostrando a o acompanhamento clínico e radiográfico periódico desta condição. Paciente, sexo feminino, nove anos de idade, caucasiana, que compareceu a Clínica Odontológica para exame de rotina. Foi solicitada uma radiografia panorâmica inicial, sendo evidenciada uma radioluscência intracoronária no dente 45 ainda não erupcionado. Foi feito uma acompanhamento clínico e radiográfico até na total estabelecimento do dente acometido na cavidade oral. Conhecer a reabsorção intracoronária pré-eruptiva, associando sua provável etiologia e aspecto radiográfico, bem como sua prevalência e ocorrência e opções de tratamento, considerando uma abordagem conservadora, quando não houver sintomatologia, como tratamento recomendado.

Termos de indexação: Cárie dentária. Radiografia dentária. Dentição permanente. Dente não erupcionado. Reabsorção de dente.

\section{INTRODUCTION}

Pre-interruptive intracoronal resorption (PEIR) is a radiolucent lesion localized in dentin, immediately below the amelodentin junction of unerupted teeth. This lesion is generally localized on the occlusal, distal or mesial surfaces of the coronal portion, extending into various depths of dentin, rarely involves the pulp and preserves the healthy crown ${ }^{1-15}$. It may be confused with caries, and mistakenly denominated "hidden caries", a term use to describe lesions that are not clinically diagnosed and are detected only in radiographs ${ }^{1-13}$.

This type of image is rare, and generally diagnosed in radiographic exams or those taken for orthodontic purposes $^{2-11}$. Although its etiology is unknown, some authors have proposed that the origin of this condition may be a developmental enamel anomaly, in which the tooth is not correctly mineralized or enamel is acquired

\footnotetext{
${ }^{1}$ Pontíficia Universidade Católica de Minas Gerais, Departamento de Odontologia. Av. Dom José Gaspar, 500, Coração Eucarístico, 30535-901, Belo Horizonte, MG, Brasil. Correspondência para / Correspondence to: SG BARRA. E-mail: < samilagbarra@gmail.com >

${ }^{2}$ Universidade Federal do Rio de Janeiro, Faculdade de Odontologia. Rio de Janeiro, RJ, Brasil.
} 
after complete coronal development, with the result of etiological factors of resorptions, such as periapical lesions of primary teeth, coronal resorption, abnormal local pressure, (due to the ectopic position of the tooth germ) or even dental caries. Few histopathological and microbiological results have sustained the hypothesis that these lesions were of a carious nature while the teeth remain unerupted ${ }^{1,6-9,12}$. No association has been found between pre-eruptive intracoronal radiolucence and gender, racial predilection, medical conditions, systemic factors and the use of fluoride ${ }^{6,9}$

The teeth most frequently involved are the mandibular second premolars and third molars, with the molars being the most affected 2,5-9,13. However, in the literature there are some cases relating affected first molars and canines ${ }^{4,9,13}$. The prevalence in primary dentin is still unknown ${ }^{11}$.

The lesion may vary according to the patient's age and the radiographic technique performed ${ }^{7,10}$. Techniques such as the interproximal type do not always clearly represent the maxillary permanent teeth in a patient with mixed dentition, therefore panoramic radiography is the type of choice for evaluating the patient, because it is capable of enabling visualization of the patients entire dentition ${ }^{7,10}$.

Some of these defects may have rapid progression, reaching close to the pulp, leading to painful symptoms, and in these cases surgical intervention of the affected tooth is advisable. Nevertheless, in the majority of cases lesion progression is minimal, and it is possible to perform conservative treatment, preserving the tooth until the time of its complete eruption 1-5,10-11,13.

The aim of this study was to report a clinical case of PEIR, showing the importance of periodic exams and correct radiographic interpretation for better diagnosis, and definition of the treatment.

\section{CASE REPORT}

The patient, a 9-year-old Caucasian girl, asymptomatic, was submitted to a routine exam. An initial panoramic radiograph was requested, which showed an intracoronal radiolucence in tooth 45 that had not yet erupted. The tooth was shown to be retained without being contact with the oral medium, thus eliminating the hypothesis of dental caries (Figure 1).

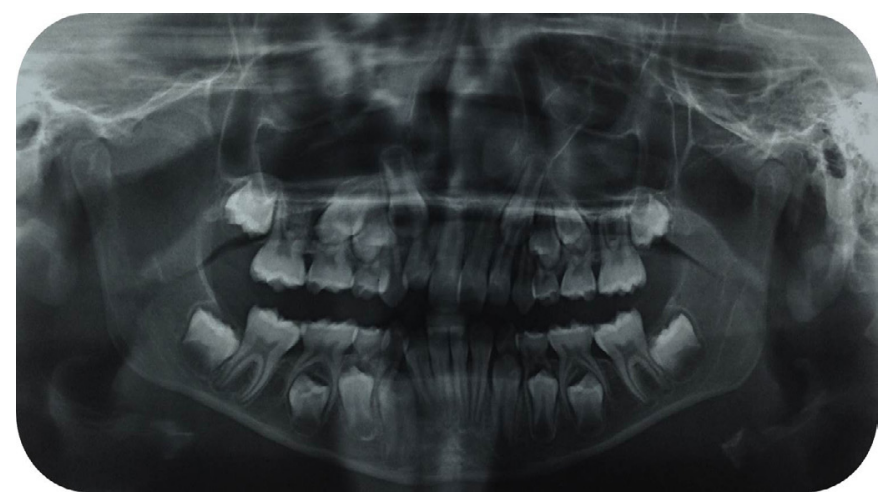

Figure 1. Panoramic radiograph showing the tooth retained without contact with oral medium.

The best treatment option in this case was followup to minimize the risk of caries, and obtain stabilization of the lesion. A new panoramic radiograph was taken after 6 months, and tooth 45 was found to be in the process of eruption, with absence of painful symptoms and increase in the lesion (Figure 2).

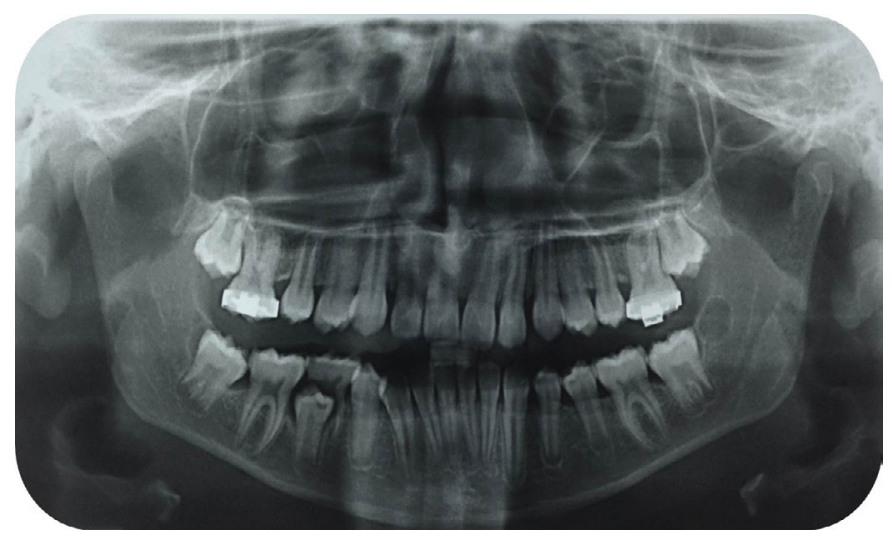

Figure 2. Panoramic radiograph showing the tooth in process of eruption.

After 4 years of follow-up, there was no progression of the lesion and the patient is at present undergoing orthodontic treatment. Another panoramic radiograph was taken, in which tooth 45 was shown in the mouth, without progression of the lesion. The treatment option was to continue the follow-up until conclusion of the orthodontic treatment so that future esthetic treatment of the tooth could be performed (Figure 3). 


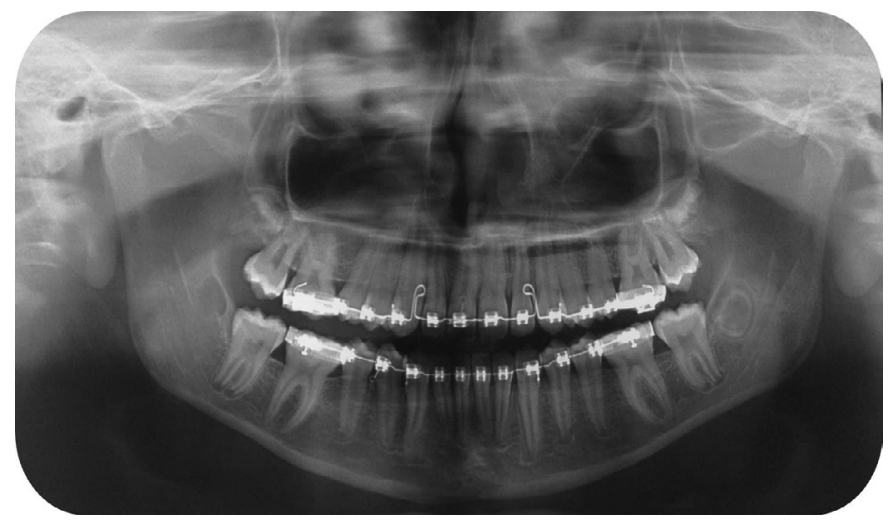

Figure 3. Panoramic radiograph showing the tooth in mouth, without progress of the lesion.

\section{DISCUSSION}

PEIR has been described as a lesion with idiopathic etiology, however, there are various hypotheses proposed by the literature, such as, for example that the permanent successor tooth would be affected by a periapical inflammation of the primary tooth ${ }^{12-13}$. However, in the case presented, the primary tooth was shown to be healthy, thus eliminating this hypothesis.

For some authors, PEIR arises from a dentin mineralization defect together with an enamel defect during formation of the crown ${ }^{12}$. Whereas, other authors have defended the hypothesis that the radiolucence presented in the radiograph of unerupted teeth may be of a carious origin ${ }^{11}$. However, the justification was that this could not occur before the eruption of a tooth. The possibility of pre-eruptive caries without the tooth being exposed to the oral medium is highly suspect, and there has been little histopathological and microbiological evidence to affirm this hypothesis ${ }^{12}$.

The physiopathology of these lesions could also be explained by the inflammatory resorption cells. These invade the protective dental epithelium of the unerupted permanent tooth crown, and thus the lesion becomes radiographically evident after development of the crown. Therefore it was an intrinsic mineralization defect. However, for this hypothesis, histopathological confirmation is necessary ${ }^{5}$.

Dental anomalies have also been related as being etiological factors, such as the ectopic position of the unerupted permanent tooth. Due to the ectopic position of the unerupted tooth and the tooth adjacent to it, there could be local pressure resulting in damage to the protective layer of the tooth, and thus it would be easily invaded by cells that would cause a resorption ${ }^{3,7}$.

Conservative treatment is recommended when the tooth presents no symptoms; this consists of periodic radiographic follow-up until the tooth erupts so that intervention can be performed. Sometimes, grooves and folds are observed on the occlusal surface of affected teeth, causing a failure in the protective enamel covering. These regions become site of risk for caries. Therefore, some authors have reported the use of sealant until the tooth erupts completely in the oral cavity, to prevent the development of caries during the course of follow-up ${ }^{9-11}$.

However, in the case of lesion progression attaining the pulp of the tooth, as in the clinical case presented, symptoms occur, and the treatment of choice is surgical intervention, exposing the tooth for the purpose of pain relief. Treatments such as pulp protection or pulpectomy are performed in cases in which the pulp is affected. In the literature there are reports of rare cases in which the lesion progressed rapidly, and extraction of the tooth was indicated ${ }^{1-2,4-7,10}$.

PEIR consists of a large proportion of hidden lesions that may progress. As they are lesions diagnosed in routine radiographs of children and young adults, as a protocol it has been suggested that all radiographs in this age-range should be examined with the purpose of discovering any change in unerupted teeth and those in the process of development, allowing early diagnosis and treatment of these lesions, thus obtaining a favorable prognosis in this condition ${ }^{8}$.

\section{CONCLUSION}

Having knowledge of PEIR, associating its probable etiology and radiographic aspect, prevalence and occurrence, helps professionals to make the correct diagnosis and definition of treatment.

\section{Collaborators}

The authors SG BARRA and MIOB VILLALOBOS contributed on the conception and drafted the manuscript. CVSR PENIDO and ACB RECCHIONI contributed to clinical procedure, data analysis, and interpretation and drafted the manuscript. MAPG VISCONTI contributed to design and critically revised the manuscript. All authors gave final approval and agree to be accountable for all aspects of the work. 


\section{REFERENCES}

1. Counihan KP, O'Connell AC. Case report: pre-eruptive intracoronal radiolucencies revisited. Eur Arch Paediatr Dent. 2012;13(4): 221-26.

2. Uzun I, Gunduz K, Canitezer G, Avsever H, Orhan K. Prevalence and characteristics of intracoronal resorption in unerupted teeth in the permanent dentition: a retrospective study. Oral Radiol. 2009;25 (1):6-13.

3. Holan G, Eidelman E, Mass E. Pre-eruptive coronal resorption of permanent teeth: report of three cases and their treatments. Pediatr Dent. 2004;16(5):373-73.

4. Omar S, Choi J, Nelson B, Shin M, Chen JW. Pre- eruptive Intracoronal Resorption (PEIR): literature review and case report. J Calif Dent Assoc. 2015;43(5):255-60.

5. Seow WK, Hackley D. Pre-eruptive resorption of dentin in the primary and permanent dentitions: case reports and literature review. Pediatr Dent. 1996;18(1):67-71.

6. Seow WK, Wan A, McAllan LH. The prevalence of pre-eruptive dentin radiolucencies in the permanent dentition. Pediatr Dent. 1998;21(1):26-33

7. Seow WK, Lu PC, McAllan LH. Prevalence of pre-eruptive intracoronal dentin defects from panoramic radiographs. Pediatr Dent. 1999;21(6):332-39.

8. Seow WK. Pre-eruptive intracoronal resorption as an entity of occult caries. Pediatr Dent. 2000;22(5):370-76.
9. Seow WK. Multiple pre-eruptive intracoronal radiolucent lesions in the permanent dentition: case report. Pediatr Dent. 1998;20(3):195-8.

10. Spierer WA and Fuks AB. Pre-eruptive intra-coronal resorption: controversies and treatment options. J Clin Pediatric Dent. 2014;38(4):326-8.

11. Moskovitz M, Holan G. Pre-eruptive intracoronal radiolucent defect: a case of a nonprogressive lesion. J Dent Child (Chic). 2004;71(2):175-78.

12. Czarnecki G, Morrow M, Peters M, Hu J. Pre-eruptive intracoronal resorption of a permanente first molar. J Dent Child (Chic). 2014; 81(3):151-5.

13. Wong $L$, Khan $S$. Occult caries or pre-eruptive intracoronal resorption? A chance finding on a radiograph. Pediatric Dent. 2014;36(5):429-32.

14. Wood PF, Crozier DS. Radiolucent lesions resembling caries in the dentine of permanent teeth. A report of sixteen cases. Aust Dent J. 1985;30(3):169-73.

15. Ignelzi MA, Fields HW, White RP, Bergenholtz G, Booth FA. Intracoronal radiolucencies within unerupted teeth: case report and review of literature. Oral Surg Oral Med Oral Pathol. 1990;70(2):214-20.

Received on: 18/5/2017

Final version resubmitted on: 26/6/2017

Approved on: 4/7/2017 